\title{
Short Communication: Agricultural biodiversity and economic productivity of the yards in Arguni Bawah, Kaimana District, West Papua Province, Indonesia
}

\author{
ALFRED ALFONSO ANTOH ${ }^{1, \bullet}$, NURHAYATI H.S. ARIFIN ${ }^{2}$, M.A. CHOZIN ${ }^{3}$, HADI SUSILO ARIFIN ${ }^{2}$ \\ ${ }^{1}$ Program of Environmental Science and Natural Resources Management, Graduate School, Institut Pertanian Bogor. Jl. Pajajaran, Kampus IPB \\ Baranangsiang, Bogor 16144, West Java, Indonesia. Tel./fax.: +62-251-8332779, `email: alfred.antoh@gmail.com \\ ${ }^{2}$ Departement of Landscape Architecture, Faculty of Agriculture, Institut Pertanian Bogor. J1. Raya Dramaga, Bogor 16890, West Java, Indonesia \\ ${ }^{3}$ Departement of Agronomy and Horticulture, Faculty of Agriculture, Institut Pertanian Bogor. J1. Raya Dramaga, Bogor 16890, West Java, Indonesia
}

Manuscript received: 18 December 2018. Revision accepted: 17 March 2019.

\begin{abstract}
Antoh AA, Arifin NHS, Chozin MA, Arifin HS. 2019. Agricultural biodiversity and economic productivity of the yards in Arguni Bawah, Kaimana District, West Papua Province, Indonesia. Biodiversitas 20: 1020-1026. Papua Island, Indonesia has abundance of agricultural biological resources. This is reflected in a variety of agricultural products in different parts of the area and in the use of yards, which is not fully utilized. This study was aimed at mapping the agricultural biodiversity of the yards, as well as measuring their economic productivity. The study area was Arguni Bawah Sub-district, Kaimana District, West Papua Province, Indonesia, and the study was conducted from November 2017 to March 2018. The average number of plant species recorded from yards were 13, number of individuals being 72 in an average yard size of $696 \mathrm{~m}^{2}$. The smallest yard was $231 \mathrm{~m}^{2}$ with only three species and 4 individuals. The maximum number of species found were 26 with 267 individuals. The maximum size of yards studied was $3,000 \mathrm{~m}^{2}$. There are five functional types of plants with high density and SDR, there are the species producing starch (taro and banana), vegetables (gedi and spinach), fruits (banana) and ornamentals, among others. The Shanon-Wiener diversity index ( $\left.\mathrm{H}^{\prime}\right)$ ranged from 1.8 to 2.5 , indicating that the biodiversity of plant species in the yards may be interpreted as abundant or moderate. The evaluation of economic productivity showed that average cash income received by households from yards was Rp.7,693,000.
\end{abstract}

Keywords: Agricultural biological resources, food security, productivity value, summed dominance ratio

\section{INTRODUCTION}

The study of yards with respect to their ecological and socio-cultural significance aims mainly at exploring plant diversity and the various ways society makes use of yards for their daily needs. According to Linger (2014), the practice of yards with an agroforestry approach is able to provide the needs of the community from the socioeconomic aspects, ecological services for farmers, and valuable aspect for micro-climate regulation. Agricultural constraints faced by farmers are more of physical constraints, namely water management, soil acidity, $\mathrm{Al}$ and $\mathrm{Fe}$ toxicity, pest and disease, thick peats, and soil subsidence (Wildayana and Armanto 2018). Agroforestry approaches in ecological zones of Papua can be practiced. It varies greatly from coastal areas, islands to lowlands and highlands or mountainous peak areas. According to Mohri et al. (2013) "traditionally, the yard is also able to maintain and protect ecosystems with high biodiversity, especially in urban areas, but does not necessarily change society participation from substantive agricultural activities to commercial agriculture." Natives of Kaimana District of West Papua Province still grow, consume, and sell such crops. However, they only take it to the market to sell when the crop produces abundantly.

Yards have significant roles in social and economic life of farm households. That is why they are often referred to as living barns, living stalls or living pharmacies. Consequently, some species of medicinal plants beneficial in curing diseases traditionally are commonly planted in yards (Ashari et al. 2012). In Indonesia, yards were developed to improve the life of the society members in areas such as: (i) ornamentals, (ii) fruits, (iii) vegetables, (iv) herbs, (v) medicinal plants, (vi) starch-producing crops, and (vii) industrial raw materials plant. They also serve other purposes such as providing firewood, shade materials, and materials for handicrafts (Arifin et al. 2012, 2013). Yard also have the ability to protect high biodiversity ecosystems, especially in rural areas. In Indonesia, yards were developed to meet needs of people, such as ornamental plants, fruits, vegetables, herbs, medicines, starch products, etc. (Arifin 2013). In addition to the planting of a variety of plant species, various types of livestock also maintained in yards.

The yards in the Arguni Bawah Sub-district, Kaimana district, West Papua Province of Indonesia are not optimally utilized. They are still traditionally structured and have not been used intensively by the locals. To increase the productivity, there is a need for integration between plants and animals or fish resources that can offer diverse economic benefits which in turn contribute to the welfare of the residents and enrich their agroforestry techniques. This move will render the yards more productive, especially when filled with different types of plants. The 
techniques developed in the yards involves planting trees along with annual crops. In the area, garden plants can be compared across similar crop (monoculture) with diverse plants (polyculture) to determine the equity value (NKL). Generally, a courtyard with similar plants and productivity mixture has a different value (Cameron et al. 2012). NKL compares between species of plants developed as mixtures and monocultures.

The main objectives of this research are to determine the agricultural biodiversity and economic productivity of the yards in the 15 villages of the Arguni Bawah Subdistrict, Kaimana District, West Papua Province, Indonesia.

\section{MATERIALS AND METHODS}

The research was conducted in the Arguni Bawah Subdistrict, Kaimana District, West Papua Province, Indonesia. It included 15 villages, namely Kufuriai, Manggera, Egerwara, Wermenu, Ruara, Tenusan, Jawera, Urisa, Waromi, Sumun, Serara, Ukiara, Nagura, Inary and Wanoma (Figure 1). The study was conducted for a period of 5 months, from November 2017 to March 2018.

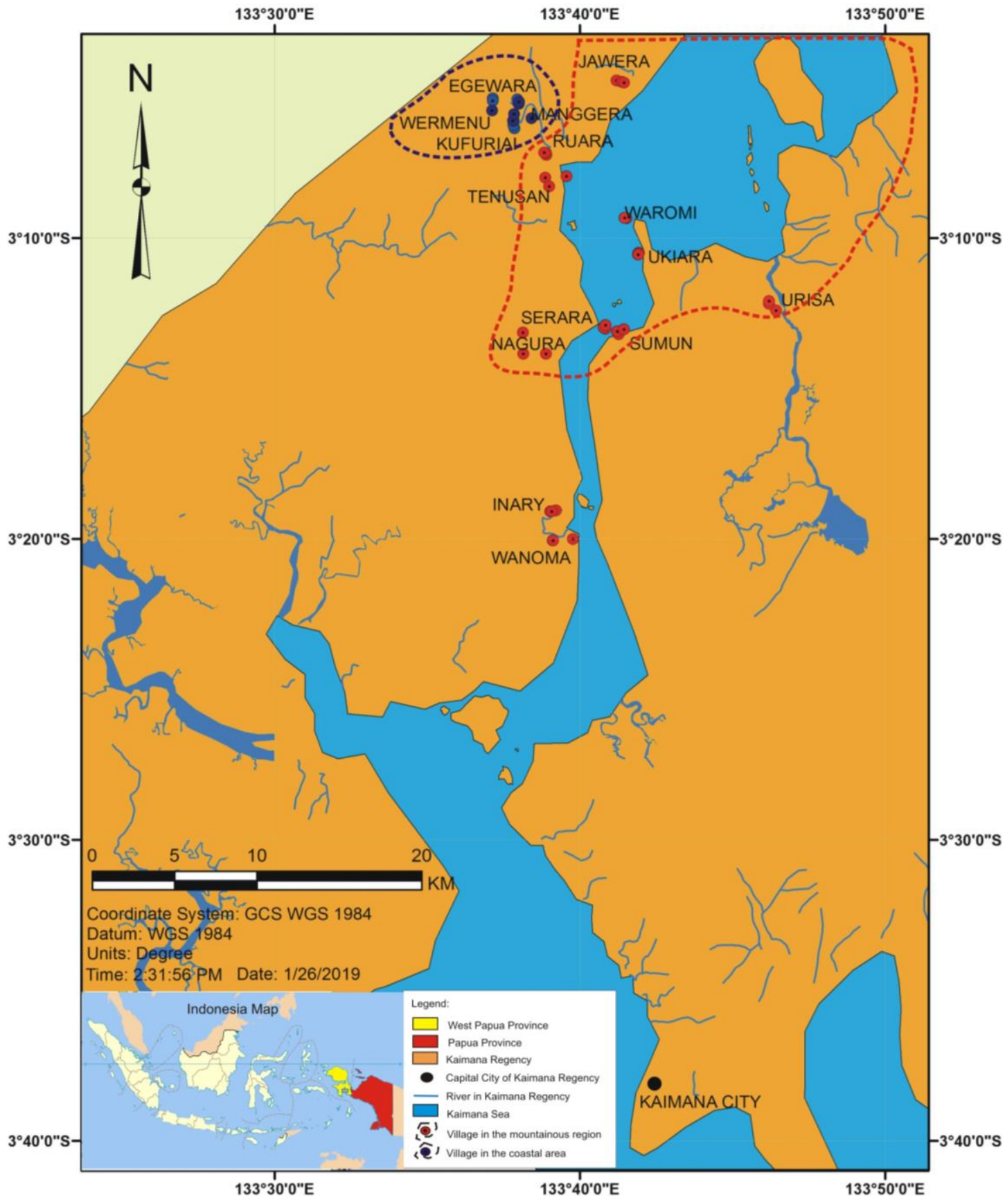

Figure 1. The map of 15 villages in the Arguni Bawah Sub-district, Kaimana District, West Papua Province, Indonesia 
The tools used in the study included: GPS, digital cameras and recorders, questionnaire sheet and maps. The samples consisted of 45 yards chosen considering the geographical position of the villages, such as on the coast near the beach, the center and the most distant parts from the coastline. The yards in Indonesia can be classified into four types based on their extent as narrow $\left(120 \mathrm{~m}^{2}\right)$, medium (120-400 $\left.\mathrm{m}^{2}\right)$, large (400-1000 $\left.\mathrm{m}^{2}\right)$ and very large (> 1000m²) (Arifin 2013). Data were collected using questionnaires and by the use of the agroforestry practice. Interview technique adopted with direct field measurements on aspects such as area and inventory of plants in the yards. Deep interviews were also conducted to explore socio-cultural information pertaining to yards. It was related to plant utility functions in finding value benefits and ecological roles for community yards in 15 villages. Measurements of vertical diversity were carried out around the sample villages (front, side, and back). The vertical diversity of yards is a form of diversity based on stratification (height) of plants in the yards.

Data was collected through survey methods including observation, documentation, and direct measurements in the field. Various aspects regarding the agricultural biodiversity of the yards were calculated as follows (Fachrul 2007):

$$
\begin{aligned}
& \text { Density }=\frac{\text { total number of plants }}{\text { total of unit sample }} \\
& \% \text { Relative density }=\frac{\text { total of individuals of a species } x 100 \%}{\text { total of individuals of all species }}
\end{aligned}
$$

Frequency $=$ total of "sampling unit" belong to one type total of "sampling unit"

$\%$ Relative frequency $=\frac{\text { frequency total of a type } \times 100 \%}{\text { total of frequency value of all types }}$

Domination $=$ basal number of one area

basal number of entire area

$\%$ Domination $=$ total of basal area of type $\times 100 \%$ total of closing value of all type

$\mathrm{INP}=\mathrm{FR}+\mathrm{KR}+\mathrm{DR}$

Where:

INP: important value index (Fachrul 2007)

FR: relative frequency

DR: relative dominance

KR: relative density

$\mathrm{SDR}=\frac{\mathrm{INP}}{\mathrm{a}} \times 100 \%$

SDR: summed dominance ratio (Fachrul 2007)

$H^{v}=\sum_{i: 1}^{S}$ piln $(p i)$
Where:

$\mathrm{H}^{\prime}$ : Index Shannon-Wiener diversity

$\mathrm{Pi}: \mathrm{ni} / \mathrm{n}$

$\mathrm{Ni}$ : Number of individuals kind of $\mathrm{i}$

$\mathrm{N}$ : Number of individuals of all species

$\ln$ : natural logarithm (natural number)

s : number of species present

Shannon-Wiener diversity index (Fachrul 2007)

$\mathrm{H}$ '> 3 Precautionary high abundant species

$\mathrm{H}^{\prime} 1 \leq \mathrm{H} ' \leq 3$ Precautionary being abundant species

$\mathrm{H} '<1$ Precautionary species of low

Production and productivity of the yard Rated Equality Area (NKL):

$$
\text { Productivity }\left(\mathrm{kg} / \mathrm{m}^{2}\right)=\frac{\text { Number of product }(\mathrm{kg})}{\text { Average size of the yard }\left(\mathrm{m}^{2}\right)}
$$

Product price received $(\mathrm{USD})=$ Amount sold $\mathrm{x}$ price per unit of enumeration

$\mathrm{NKL}=\frac{\mathrm{HA1}}{\mathrm{HB} 2}+\frac{\mathrm{HB} 1}{\mathrm{HB} 2}$ (Rifai et al. 2014)

Where:

HA1: Result A plant species planted in intercropping

HB1: Result B types of crops planted in intercropping

HA2: Result A plant species grown in monoculture

HB2: Result B plant species grown in monoculture

\section{RESULTS AND DISCUSSION}

\section{Agricultural biodiversity in West Papua yards}

The average number of species recorded from yards were 13, number of individuals being 72 in an average yard, size of $696 \mathrm{~m}^{2}$. The smallest yard was $231 \mathrm{~m}^{2}$ with only three species and 4 individuals. The maximum species found were 26 with 267 individuals. The maximum size of the yards studied was $3,000 \mathrm{~m}^{2}$ (Table 3). The Yard function was horizontal diversity of plants based on functionality, usability, and benefits for society (Arifin 1998). Other research carried out in urban areas today has developed fruit and vegetable crops that are together in skyscrapers due to land shortages (Aleksandrov 2018).

Table 3. The area, number of species and number of individuals in the yard in the Arguni Bawah Sub-district, Kaimana District, West Papua Province, Indonesia

\begin{tabular}{lrrrr}
\hline & The area $\left(\mathbf{m}^{\mathbf{2}}\right)$ & $\begin{array}{l}\text { Number } \\
\text { species }\end{array}$ & $\begin{array}{l}\text { Number } \\
\text { individuals }\end{array}$ \\
\hline Maximum & 3000 & 26 & 267 \\
Average & 696 & 13 & 72 \\
Minimum & 231 & 3 & 4 \\
SD & 468 & 5 & 56 \\
\hline
\end{tabular}


Table 4. The density and the highest SDR of 45 yards in the Arguni Bawah Sub-district, Kaimana District, West Papua Province, Indonesia

\begin{tabular}{|c|c|c|c|c|c|c|c|c|c|c|}
\hline No. & $\begin{array}{c}\text { Locations } \\
\text { village }\end{array}$ & $\begin{array}{l}\text { The average } \\
\text { area }\left(\mathbf{m}^{2}\right)\end{array}$ & $\mathbf{K}$ & INP & SDR & $\mathbf{H}^{\prime}$ & Plants & Name of species & Family & Level \\
\hline \multirow[t]{4}{*}{1} & Waromi & 576 & 108.0 & 29.9 & 9.6 & 1.9 & Taro & Colocasia sp. & Araceae & II \\
\hline & Sumun & 765 & 86.0 & 17.6 & 5.9 & 2.5 & & & & \\
\hline & Serara & 379 & 75.0 & 36.6 & 12.2 & 1.9 & & & & \\
\hline & Ukiara & 694 & 75.0 & 24.4 & 8.1 & 2.0 & & & & \\
\hline \multirow[t]{2}{*}{2} & Kufuriai & 770.3 & 27.0 & 24.4 & 8.8 & 1.8 & Edible hibiscus & Abelmoschus manihot $\mathrm{L}$. & Malvaceae & II \\
\hline & Ruara & 304 & 50.0 & 39.1 & 13.0 & 1.9 & & & & \\
\hline \multirow[t]{3}{*}{3} & Tenusan & 847.3 & 68.0 & 20.7 & 6.9 & 2.2 & Banana & Musa sp. & Musaceae & IV \\
\hline & Jawera & 882.7 & 41.0 & 17.5 & 5.9 & 2.5 & & & & \\
\hline & Nagura & 504.7 & 35.0 & 27.8 & 9.2 & 1.9 & & & & \\
\hline \multirow[t]{2}{*}{4} & Urisa & 1047 & 39.0 & 24.4 & 7.7 & 2.1 & Coconut & Cocos nucifera L.. & Arecaceae & V \\
\hline & Inary & 666.7 & 14.0 & 15.8 & 5.3 & 1.9 & & & & \\
\hline \multirow[t]{2}{*}{5} & Manggera & 1268 & 34.0 & 23.4 & 7.8 & 2.2 & Areca nut & Areca catechu. L. & Arecaceae & V \\
\hline & Egerwara & 464.3 & 13.0 & 20.2 & 6.7 & 1.9 & & & & \\
\hline 6 & Wermenu & 402 & 14.0 & 17.4 & 5.7 & 1.7 & Spinach & Amaranthus spinous & Amaranthaceae & I \\
\hline 7 & Wanoma & 606.7 & 30.0 & 23.8 & 7.9 & 1.9 & $\begin{array}{l}\text { Ornamental } \\
\text { taro }\end{array}$ & Colocasia $\mathrm{sp}$ & Araceae & I \\
\hline
\end{tabular}

Note: Strata (Arifin 2013): $\mathrm{V}=$ strata trees $>10 \mathrm{~m}, \mathrm{IV}=$ small tree/large shrub $5-10 \mathrm{~m}, \mathrm{III}=$ small shrubs, bushes $2-5 \mathrm{~m}, \mathrm{II}=$ shrubs, herbaceous $1-2 \mathrm{~m}, \mathrm{I}=$ grass $<1 \mathrm{~m}$

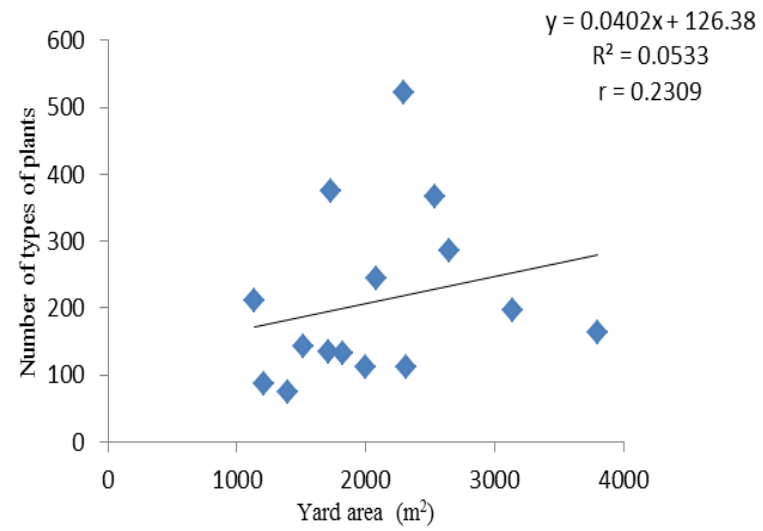

Figure 2. The relationship between the area $\left(\mathrm{m}^{2}\right)$ and the number of plants

The density, frequency, relative dominance, index (INP), and the summed dominance ratio (SDR) are calculated to identify the yard having the highest biodiversity in every village (Table 4). There are five types of plants with high density and SDR, they are the species producing starch (taro and banana), vegetables (gedi and spinach), fruits (banana), and ornamentals among others (Table 4). The taro plant is usually found in four villages, namely Waromi, Sumun, Serara, and Ukiara. On the other hand, vegetable crops were recorded in three villages Kufuriai, Ruara, and Wermenu. The fruit-bearing crops, namely banana plants, were in the villages of Tenusan, Jawera, and Nagura. Oilseeds have been observed in the villages of Urisa and Inary. Many houseplants were only found in the village of Wanoma (Table 4).

The results of calculation showed the Shannon-Wiener diversity index $\left(\mathrm{H}^{\prime}\right)$ ranged from 1.8 to 2.5 (Table 4), indicating that the biodiversity of garden plant species in the yards may be interpreted as abundant or moderate. The yard in Bogor research has diversity of food crops in moderate category $(\mathrm{H}=1.95)$, with the dominance of seasonal crops. This is different from the research carried out by Robiansyah (2018) in Tambrauw District, West Papua. It was concluded that diversity, wealth and grade in Fef were higher than in Bamusbama. For tree biomass, the estimated value in Bamusbama (383.8 tons/ha) is much higher than in Fef (224.7 tons/ha). Diversity of food crops is indicated by the various types of foods both in terms of strata as well as the functioning of plants. Food crops (medicinal plants, vegetables, fruits, herbs and sources of starch) and livestock farming is still the preference of people in the yards, for supporting their availability for daily consumption (Azra et al. 2014).

Figure 2 shows a linear relationship between the area of yards and the number of plants, producing $\mathrm{R} 2$ value of 0.0533. It can, therefore, be said that the area of the yard was only able to describe the diversity of the number of plant species at $05.33 \%$, leaving the rest to be explained by other variables. The correlation value of 0.2309 indicated a positive relationship between the size of yards and diversity of plants, though it is relatively weak. This means that the average sized yard can be developed with other local commodities such as carbohydrate-producing crops, vegetables, herbs, medicinal plants, and fruit trees in the Arguni Bawah Sub-district. On the other hand, an increase in acreage of lawn can increase the cost of inputs such as fertilizer externalities in case there is a need to increase productivity (Guuroh et al. 2014).

Besides the plants of the yards, their livestock potential can also be developed. The data in Table 5 provides the livestock details in the yards. The results show that the number of livestock held in an average yard, probably 696 $\mathrm{m}^{2}$, was only sixteen. By maximum utilization of the area, 
it is possible to support up to 13 cows in a yard area of $3,000 \mathrm{~m}^{2}$. Productivity is quite minimal if the total area is $231 \mathrm{~m}^{2}$. Furthermore, multiple linear regression tests to see broad capabilities and capacity of the livestock yard can be developed.

Figure 3 shows the relationship between the area of yards and the number of livestock which is broadly parabolic. Relations on the model produced $\mathrm{R}^{2}$ value of 0.1608 implying that the area of the yards is only able to account for $16.08 \%$ of the livestock population, leaving the rest to be explained by other variables. The correlation value of 0.0858 indicates weak positive relationship between the area of yards and number of livestock. Different varieties of Livestock can be reared in the yards. Keeping of livestock, both large ones such as cattle, goats and pigs, and small ones like ducks can be improved in the yards. Maintenance of livestock should take into account other significant factors to support their productivity. Large and small cattle developed maximally in area of 2000-3000 $\mathrm{m}^{2}$ (Figure 3). Increasing productivity in the small to medium scale production systems is constrained by lack of skills, knowledge and appropriate technologies, as well as insufficient access to markets, goods and services, and weak institutions (FAO 2018).

Table 5. The area $(\mathrm{m} 2)$ and the number of cattle in the Arguni Bawah Sub-district Kaimana District, West Papua Province, Indonesia

\begin{tabular}{lcccccc}
\hline & $\begin{array}{c}\text { Area } \\
\left(\mathbf{m}^{2}\right)\end{array}$ & Cow & Goat & Pig & Chicken & $\begin{array}{c}\text { Total } \\
\text { livestock }\end{array}$ \\
\hline Maximum & 3000 & 2 & 5 & 4 & 13 & 24 \\
Average & 696 & 2 & 4 & 3 & 7 & 16 \\
Minimum & 231 & 2 & 3 & 2 & 4 & 11 \\
SD & 468 & 0 & 1 & 1 & 2 & 4 \\
\hline
\end{tabular}

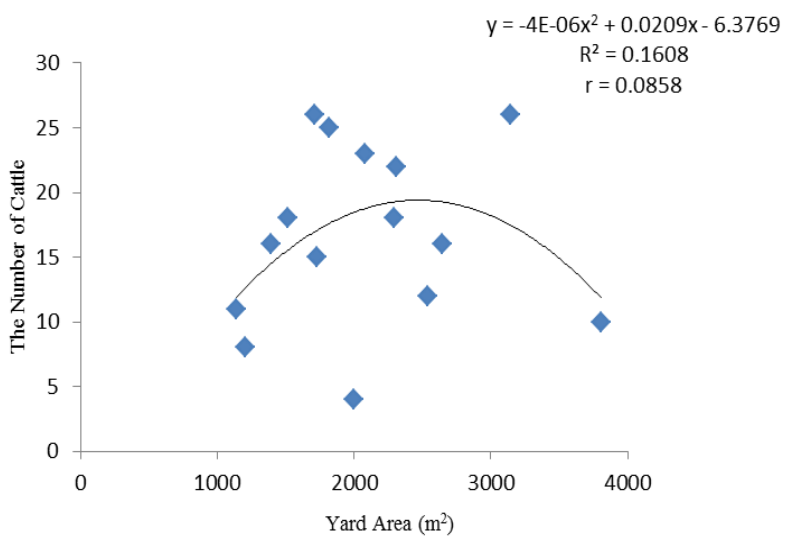

Figure 3. The relationship between the area $\left(\mathrm{m}^{2}\right)$ of yards and the number of livestock
The result is that both production and productivity remain below potential, and losses and wastage can be high. However, adapted breeds, local feed resources, and animal health interventions are available, along with improved and adapted technologies that include sound animal husbandry, on and off-farm product preservation and value-adding product processing. Together with supportive policies and institutions, they have the potential to improve productivity, income generation substantially and to make a significant contribution to poverty reduction (FAO 2018). In addition, other studies have also shown that for livestock development a horti-pastoral system can be introduced in the yard. The Hortipastoral system can be a solution, it seems, perhaps not only in meeting the increasing demand for fruit and animal feed in a sustainable manner, but also in increasing productivity and overall system sustainability. Efforts have been made to review the potential status of forages, livestock resources and produce forages around their environment (Ahmad et al. 2017).

\section{Productivity of yards}

Farming households have different abilities to produce food from different sources. Like gardens, mixed gardens, and yards. Food production is largely determined by the number of species and area of the system. Productivity measured here is related to yields harvested from the yards and sold to the market by farm households in rupiah. Yard plants have different functions and roles in each household. Yard plants and their products are used for domestic consumption by farm households and excess are sold in the market. The sale of garden plant products can increase income for farmer households and is expected to provide additional welfare for them. Mostly seasonal plants are grown in the yards and harvesting depends on the harvest season. The data regarding productivity of yards in the study area is given in Table 6.

The above results showed that average cash income received by households from yards was Rp.7,693,000 (table 6). If an area planted taro had smaller incomes (Rp 133,000/yard) (Table 6). Evidently, Yard development can generate a lot of income for family households. For instance, nutmeg plants have a high income, but they can be harvested only twice within a year, every April and October. This is also supported by previous research on the value of equality which has shown that the overall NKL for sugarcane and soybeans has a value greater than one so that intercropping is more efficient and productive compared to monocultures (Rifai et al. 2014). Other studies also show that the highest yield ratio of food crops is obtained for upland rice plants and the lowest for corn plants. From the various cropping patterns tested, the results showed that intercropping patterns of jatropha, peanut and sunflowers were better for growth and the value of land equity (NKL) (Prasetsyo et al. 2009). 
Table 6. The average economic productivity of 45 yards based on products marketed in the Arguni Bawah Sub-district, Kaimana District, West Papua Province, Indonesia

\begin{tabular}{|c|c|c|c|c|c|c|c|}
\hline Products from yards & Unit & $\begin{array}{c}\text { Designation } \\
\text { term (unit) }\end{array}$ & Volume & $\begin{array}{c}\text { Total sale } \\
\text { (unit) }\end{array}$ & $\begin{array}{c}\text { The unit price } \\
\text { of enumeration } \\
\text { (in rupiahs) }\end{array}$ & $\begin{array}{c}\text { Price } \\
\text { year 2014* } \\
\text { (in rupiahs) }\end{array}$ & $\begin{array}{c}\text { Total } \\
\text { productivity } \\
\text { (in rupiahs) }\end{array}$ \\
\hline Great taro & 3 pieces & Local & 80 & 26 stacks & 5,000 & 5,000 & 133,000 \\
\hline Small taro & 5 pieces & Local & 120 & 24 stacks & 5,000 & 5,000 & 120,000 \\
\hline Sago & $15 \mathrm{~kg}$ & general & 3 & $450 \mathrm{~kg}$ & 150.000 & 120,000 & 450,000 \\
\hline Banana & 1 bunch & Local & 4 & 4 bunches & 100,000 & 100,000 & 400,000 \\
\hline Areca nut & 5 seeds & Local & 100 & 20 stacks & 5,000 & 5,000 & 100,000 \\
\hline Nutmeg seed & $\mathrm{kg}$ & General & 150 & $150 \mathrm{~kg}$ & 12,000 & 10,000 & $1,800,000$ \\
\hline Nutmeg flower & $\mathrm{kg}$ & General & 15 & $15 \mathrm{~kg}$ & 100,000 & 75,000 & $1,500,000$ \\
\hline Durian & fruit & Local & 60 & 60 pieces & 25,000 & 20,000 & $1,500,000$ \\
\hline Mango & 10 pieces & Local & 150 & 15 stacks & 10,000 & 7,500 & 150.000 \\
\hline Edible Hibiscus & $20 \operatorname{rod}$ & Local & 400 & 20 bond & 2,000 & 2,000 & 40,000 \\
\hline Kale & $20 \mathrm{rod}$ & Local & 600 & 30 bond & 2,500 & 2,000 & 75,000 \\
\hline Spinach & $30 \mathrm{rod}$ & Local & 600 & 20 bond & 2,500 & 2,000 & 40,000 \\
\hline Tomato & stack & Local & 10 & 10 stacks & 10,000 & 10,000 & 100,000 \\
\hline Cayenne pepper & stack & Local & 15 & 15 stacks & 80,000 & 50,000 & $1,200,000$ \\
\hline Coconut & Fruit & Local & 85 & 85 pieces & 1,000 & 1,000 & 85,000 \\
\hline \multicolumn{7}{|c|}{ The average amount of cash income per family from the yard } & $7,693,000$ \\
\hline
\end{tabular}

Note: * Data from survey of farmer exchange rate in 2014 by LH BAPPEDA Kaimana, West Papua Province, Indonesia

The intercropping systems with agroforestry techniques are important for development in the region. The results of other research on the benefits of cropping system proved that tomato plants in mixed farming have reduced damages compared to monoculture system (Ulinnuha et al. 2017). Development yards, besides providing additional income to the people, also contribute to ecological improvements of the area.

Other researches show that the most popularly grown plants in the yards are bananas. Plants that are grown by at least $25 \%$ of the families are guava, mango, and ornamental plants. Cassava and bulbous plants (such as sweet potatoes) are planted by $13 \%$ and $10 \%$ of the total respondents, respectively. Fruit trees are far more than others such as bananas (47\%), papaya (24\%), guava (29\%) and mango (34\%). Only Dogfruit and chili were planted by $18 \%$ and $10 \%$ of respondents, respectively, and tomatoes were planted by $8 \%$ of households. Many types of seasonal vegetables such as leeks, celery, tomatoes, eggplant, long beans, spinach, and sweet leaf are planted in less than $8 \%$ of the total household (Arifin 2008).

Another study has shown the small-scale farms have an important role in the development of the agricultural and rural areas in Bulgaria (Dirimanova 2018). Research showed in Azerbaijan that Taking into consideration that price and production cost is the main index in comparison competitiveness in agriculture in research; it has been applied to theoretical thoughts and research work about these categories. Among indices used in the study of current situation and competitiveness in agriculture, it is emphasized role of macroeconomics, economic and financial index. Research showed in Azerbaijan that taking into consideration that price and production cost is the main index in comparison competitiveness in agriculture in research; it has been applied to theoretical thoughts and research work about these categories. Among indices used in study of current situation and competitiveness in agriculture, it is emphasized role of macroeconomics, economic and financial index. In analysis part, it is introduced models that reflect dependent on selling price of agricultural product on prime cost and labor cost which is main factor in increase of agriculture (Humbatova et al. 2018). The results of research in Bangladesh (Anik et al. 2018) show that onion production is determined by factors such as land, labor, seeds and modern varieties.

\section{ACKNOWLEDGEMENTS}

The research team wishes to offer special gratitude to the Indonesian Ministry of Technology Research and Higher Education for the grants in 2018 with the contract number 02/UN20.2.2/PL/PD/2018. The research grant was very helpful for the successful completion of the study.

\section{REFERENCES}

Ahmad S, PA Khan, DK Verma, N Mir, JP Singh, I Dev, JM Roshetko. 2017. Scope and potential of hortipastoral system for enhancing livestock productivity in Jammu dan Kashmir. Indian J Agrofor 19: 48-56.

Aleksandrov Y. 2018. New solution-cultivation of soft fruits and vegetables in a superskyscraper in Hong Kong. Bulgarian J Agric Sci 24 (1): 151-157.

Anik AR, MDA Salam, S Rahman. 2017. Divers of production and efficiency of onion cultivation in Bangladesh. Bulgarian J Agric Sci 23 (1): 34-41.

Arifin HS, Munandar A, Mugnisjah WQ, Arifin NHS, Budiarti T, Pramukanto Q. 2008. Revitalisasi Pekarangan sebagai Agroekosistem dalam Mendukung Ketahanan Pangan di Wilayah Perdesaan. Seminar Nasional "Strategi Penangan Krisis Sumberdaya Lahan untuk Mendukung Kedaulatan Pangan dan Energi. Faperta IPB, Bogor, 2223 Desember 2008. [Indonesian]. 
Arifin HS, Munandar A, Schultink G and Kaswanto RL 2012. The role and impacts of small-scale, homestead agro-forestry system"pekarangan"on household prosperity: an analysis of agroecological zones of Java, Indonesia. Intl J AgriSci 2: 869-914.

Arifin HS. 2013. Pekarangan Kampung untuk Konservasi AgroBiodiversitas dalam Mendukung Penganekaragaman dan Ketahanan Pangan di Indonesia. Guru Besar Tetap Fakultas Pertanian Instutut Pertanian Bogor. Orasi Ilmiah Guru Besar IPB 14 Desember 2013. Bogor . [Indonesian]..

Arifin HS. 2013. Pekarangan Kampung untuk Konservasi AgroBiodiversitas dalam Mendukung Penganekaragaman dan Ketahanan Pangan di Indonesia, 14 Desember 2013. [Indonesian].

Ashari, Saptana, Purwantini TB. 2012. Potensi dan Prospek Pemanfaatan Lahan Pekarangan untuk Mendukung Ketahanan Pangan. Forum Penelitian Agro Ekonomi. 1: 13-30. [Indonesian]

Azra ALZ, Arifin HS, Astawan M, Arifin NHS. 2014. Analisis karakteristik pekarangan dalam mendukung penganekaragaman pangan keluarga di Kabupaten Bogor. Jurnal Lanskap Indonesia 6: 111. [Indonesian]

Bappeda LH. 2015. Analisis potensi dan strategi pemberdayaan ekonomi lokal masyarakat berdasarkan karakteristik wilayah Distrik di Kabupaten Kaimana, Badan Perencanaan Pembangunan Daerah dan Lingkungan Hidup, Kaimana.

Cameron RWR, Blanusa T, Taylor JE, Salisbury A, Halstead AJ, Henrico B, Thompson K.. 2012. The domestic garden-Its contribution to urban green infrastructure. Urban For Urban Green J 11: 129-137.

Dirimanova V. 2018. The role of the extension services for the development of the small-scale farm in Bulgaria. Bulgarian J Agric Sci 24: 35-39.

Fachrul MR. 2007. Metode Sampling Bioekologi. Penerbit Bumi Aksara, Jakarta. [Indonesian]

FAO. 2018. Agriculture and consumer protection department. Anima production and health 1: 23. Food and Agriculture Organization, Rome.
Guuroh RT, H Uibrig, E Acheampong. 2014. How does home garden size affect input and output per unit area?-a case study of the Bieha District, Southern Burkina Faso. Intl J Agrisci 4: 196-208.

Humbatova SI, NG-O Hajiyev, RKH Gasimov, SM Tanriverdiev. 2018. Interaction of Production Cost, Price, and Labour in Increase of Competitiveness in Agrarian sector of Azerbaijan. Bulgarian J Agric Sci 24: 23-34.

Linger E. 2014. Agro-ecosystem and socio-economic role of homegarden agroforestry in Jabithenan District, North-Western Ethiopia: implication for climate change adaptation. Springerplus 3: 154-160.

Mohri H, Lahoti S, Saito O, Mahalingam A, Gunatilleke N, Irham, Hoang VT, Hitinayake G, Takeuchi K, Herath S. 2013. Assessment of ecosystem services in homegarden systems in Indonesia, Sri Lanka, and Vietnam. Ecosyst Serv 5: 124-136.

Prasetyo, EI Soekardjo, H Pujiwati. 2009. Produktivitas lahan dan NKL pada tumpangsari jarak pagar dengan tanaman pangan. Jurnal Aktaagrosia 12: 51-55. [Indonesian]

Rifai A, Basuki S., Utomo B.. 2014. Nilai kesetaraan lahan budidaya tumpang sari tanaman tebu dan kedelai: studi kasusdi Desa Karangharjo, Kecamatan sulang, Kabupaten Rembang. Widyariset 17: 59-70. [Indonesian]

Robiansyah, I. 2018. Diversity and Biomass of Tree species in Tambrauw, West Papua, Indonesia. Biodiversitas 19 (2): 377-386.

Susanti, S Anwar, E Fuskhah, Sumarsono. 2014. Pertumbuhan dan nisbah kesataraan lahan (NKL) koro pedang (Canavalia ensiformis) dalam tumpang sari dengan jagung (Zea mays). Agromedia 32: 38-44. [Indonesian]

Ulinnuha Z, MA Chozin, E Santosa. 2017. Kajian Ekofisiologi Tanaman Tomat (Solanum lycopersicum) di Bawah Naungan untuk Pengembangan Sistem Tanaman Ganda. [Tesis]. Bogor Agricultural University, Bogor. [Indonesian]

Wildayana E, ME Armanto. 2018. Dynamics of landuse changes and general perception of farmers on South Sumatra Wetlands. Bulgarian J Agric Sci 24 (2): 180-188. 